\title{
Viral nerve necrosis in hatchery-produced fry of Asian seabass Lates calcarifer: sequential microscopic analysis of histopathology
}

\author{
I. S. Azad ${ }^{1,2, *}$, M. S. Shekhar ${ }^{1}$, A. R. Thirunavukkarasu' ${ }^{1}$, K. P. Jithendran ${ }^{1}$ \\ ${ }^{1}$ Central Institute of Brackishwater Aquaculture (CIBA), 75 Santhome High Road, RA Puram, Chennai 600 028, India \\ ${ }^{2}$ Present address: Aquaculture, Fisheries and Marine Environment Department, Kuwait Institute for Scientific Research, \\ PO Box 1638, Salmiya 22017, Kuwait
}

\begin{abstract}
We studied the natural progression of viral nerve necrosis (VNN) in larvae of Asian seabass Lates calcarifer Bloch from 0 to 40 days post-hatch (dph). The hatchlings were reared in the vicinity of a confirmed nodavirus-affected older batch. Using light and electron microscopy (EM), we made a sequential analysis of histopathological manifestations in nerve tissue and other organs. There were no changes from the day of hatching until $4 \mathrm{dph}$. Larvae at $4 \mathrm{dph}$ had viral particles in the intramuscular spaces underlying the skin, but the nerve cells of the brain were normal. The first signs of necrosis of the brain cells were observed at $6 \mathrm{dph}$. EM observations revealed characteristic membrane-bound viral particles measuring $30 \mathrm{~nm}$ in the cytoplasm of nerve cells of the brain, spinal cord and retina. Histological samples of fry examined when group mortalities reached 20 to $35 \%$ revealed highly vacuolated brains, empty nerve cell cytoplasm and viral particles in the intercellular spaces. Viral particles occurred extensively in the intramuscular spaces and the epidermal layers. These observations were corroborated by positive immunostaining of the virus-rich intramuscular spaces. EM studies also revealed progressive necrotic changes in the cells harboring the virus. Results emphasize the need to maintain hygiene in the hatchery environment and to develop strategies for prevention of disease spread among cohabiting seabass and other susceptible fish larvae. Intramuscular localization of the nodavirus in both preclinical healthy-looking and post-clinical moribund larvae suggests that virus neutralization strategies during larval development could be effective in controlling VNN-associated mortalities.
\end{abstract}

KEY WORDS: Viral nerve necrosis · Histopathology · Immunofluorescence $\cdot$ Electron microscopy Asian seabass · Lates calcarifer $\cdot$ VER

\section{INTRODUCTION}

Since the first report of piscine nodavirus in Barramundi Lates calcarifer (Glazebrook et al. 1990), the disease has attracted attention of several workers, resulting in the generation of an array of information on aspects of the disease in different fish species. About 30 species of fish are sensitive to this group of piscine viruses (Johansen et al. 2002, Munday et al. 2002). Popularly known as viral nerve necrosis (VNN) or viral encephalopathy and retinopathy (VER), this disease is a major problem in the farming of many fish species (Munday \& Nakai 1997, Johansen et al. 2002, Munday et al. 2002, OIE 2003). The disease also has immense implications in health management of aquarium fish following a report of VNN in guppy Poicelia reticulata (Hegde et al. 2003). We reported on the first incidence of nodavirus-related mass mortalities in hatchery-produced Asian seabass L. calcarifer from India (Azad et al. 2005). Investigations of piscine 
nodavirus infecting fish from different environments ranging from freshwater to marine have shown consistently that the virus is neurotrophic and produces clinical symptoms indicative of nerve necrosis (Glazebrook et al. 1990, Mori et al. 1992, Munday et al. 1992, Tanaka et al. 1998, Zafran et al. 1998, Skliris et al. 2001, Chi et al. 2003, Hegde et al. 2003, Johansen et al. 2004, Azad et al. 2005).

Vertical transmission of the virus through asymptomatic carrier brood fish has also been suggested (Johansen et al. 2002, Azad et al. 2006). However, several cohabitation studies indicate a possible horizontal transmission of the disease from older infected batches of larvae to the younger uninfected larvae and fry (Glazebrook et al. 1990, Arimoto et al. 1993, Le Breton et al. 1997, Skliris \& Richards 1999, Totland et al. 1999, Breuil et al. 2001, Tanaka et al. 2003). In a sequential study of pathological changes in Atlantic halibut Hippoglossus hippoglossus, Johansen et al. (2004) described an acute outbreak of viral encephalopathy and retinopathy. A comparative study of VER in juvenile seabass Dicentrarchus labrax described pathological changes (Peducasse et al. 1999), while Grotmol et al. (1999) demonstrated VER in various organs of Atlantic halibut Hippoglossus hippoglossus. The present investigation made a daily ( 0 to $40 \mathrm{dph}$ ) analysis of histopathological changes of Asian seabass during the critical and VNN-sensitive larval stages. We also suggest a possible mode of horizontal transmission from contaminated rearing environments. each tank, fixed and processed using standard tissue processing techniques for light and electron microscopy. Fig. 1 shows a diagrammatic presentation of the tank layout.

Tissue processing and microscopy. Sampled fish were fixed in $10 \%$ buffered formalin for light microscopy, and one change of fresh fixative was made $24 \mathrm{~h}$ after the first. Tissue processing, wax embedding, sectioning and staining with hematoxylin and eosin were performed following standard procedures (Roberts 1978). Larvae were processed and embedded (20 to 25 larvae per block from samples collected at 0 to $6 \mathrm{dph}$, and 5 to 6 larvae per block from samples collected at 7 to $40 \mathrm{dph}$ ) with random and sagittal orientations, such that the sections exposed different tissues for staining. Fish for electron microscopy were fixed in $2.5 \%$ glutaraldehyde for 3 to $6 \mathrm{~h}$, depending on the size of the tissue, rinsed in $0.2 \mathrm{M}$ sodium cacodylate buffer $(\mathrm{pH}$ 7.4) and post fixed in $1 \%$ osmium tetroxide. The tissues were dehydrated in ethanol and embedded in an epoxy resin (Araldite EM embedding resin). Semi-thin sections (0.5 to $1.0 \mu \mathrm{m})$ were cut using a Diatome diamond knife, and stained with toluidine blue for light microscopy in order to mark areas of interest for observation under the electron microscope. Ultra-thin sections ( 80 to $100 \mathrm{~nm}$ ) were cut, contrasted in uranyl acetate/lead citrate and observed under the electron microscope (Philips 200 C).

\section{MATERIALS AND METHODS}

Fish. We used Asian seabass larvae (0 to 40 days post hatch, dph) reared indoors in fiberglass reinforced plastic tanks of $5 \mathrm{t}$ capacity, at a stocking density of 30 to 35 larvae $\mathrm{l}^{-1}$ of water. The larvae were fed rotifers and Artemia nauplii during the second and third week. We studied fish from two $5 \mathrm{t}$ tanks containing an older batch of Asian seabass larvae that had suffered mortalities ( 70 to $90 \%$ due to VNN) and from three $5 \mathrm{t}$ tanks containing a younger batch of larvae (20 to $21 \mathrm{~d}$ younger than the VNN-positive batch). Tools, hand nets, implements and workers were common to the batches. Larval samples of surviving and moribund larvae from the VNN-positive older batch (as a probable source of VNN) were used for histopathology and RT-PCR. Also, the newly hatched larvae were sampled daily (about 20 to 100 larvae depending on size) from

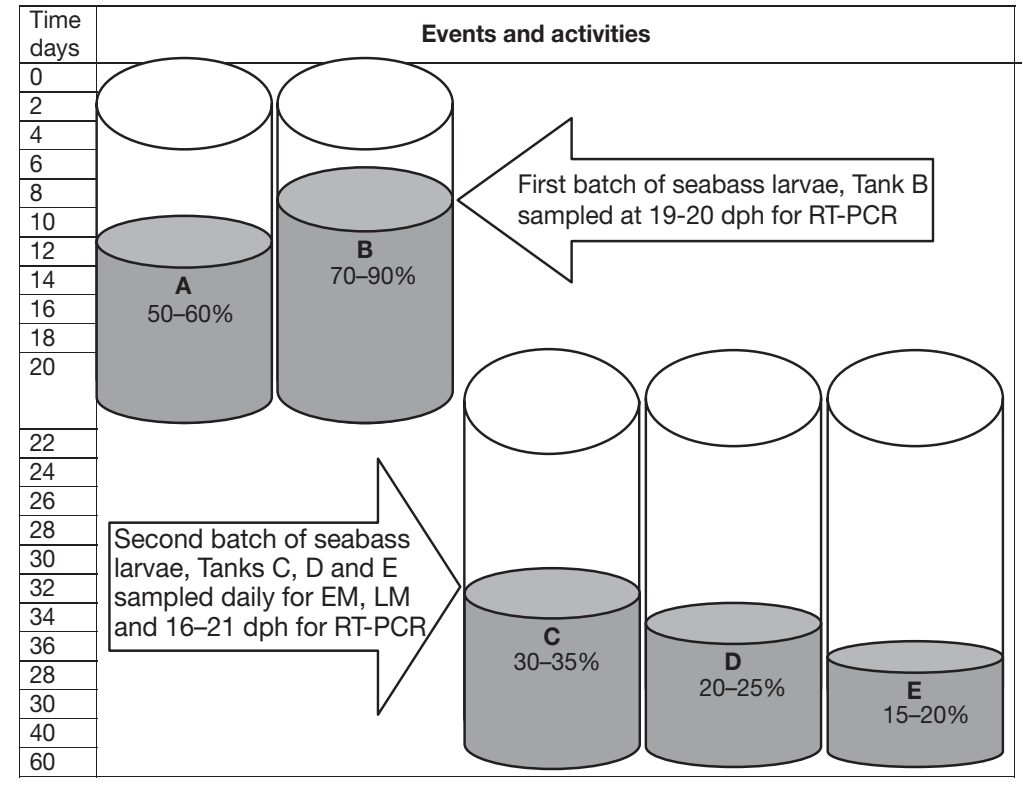

Fig. 1. Events and activities of Asian seabass larval rearing and sampling for sequential analysis of VNN histopathology (percentages indicate mortality levels with clinical VNN). RT-PCR = reverse transcriptase polymerase chain reaction; dph $=$ days post-hatch; $\mathrm{LM}=$ light microscropy; $\mathrm{EM}=$ electron microscopy 
Immunostaining. Dewaxed hydrated sections of whole larvae (4 to $6 \mathrm{dph}$ ) were used for immunofluorescence staining. Briefly, the sections were treated with trypsin $(0.1 \% \mathrm{w} / \mathrm{v}$ in biochemical grade phosphate buffered saline, PBS, HiMedia) for $10 \mathrm{~min}$ and washed twice with PBS-Tween 20 (PBST: PBS with $0.01 \%$ v/v T-20, HiMedia). Non-specific antibody binding sites were blocked for 30 min using $3 \%$ bovine serum albumin (in PBS, $\mathrm{pH}$ 7.4) and washed with PBST. The sections were treated with the first antibody (rabbit anti-SJNNV SGWak97; SEAFDEC) at a dilution of 1:50 (sterile PBS, $\mathrm{pH} 7.4$ ) for $1 \mathrm{~h}$ in a humid chamber, while the control sections were incubated with normal unimmunized rabbit serum of identical dilution. Sections were washed with PBST before treatment with goat anti rabbit-fluorescein (FITC) conjugate for $1 \mathrm{~h}$. The sections were again washed with PBST before lightly blotting and mounting in glycerol. All immunochemicals were procured from Bangalore Genei unless specified.

RT-PCR. Moribund larvae (16 to $20 \mathrm{dph}$ ) were frozen and kept at $-20^{\circ} \mathrm{C}$ or preserved in absolute alcohol for nodavirus diagnostics to confirm nodavirus-related mortalities in the batches of larval samples from tanks C, D and E (Fig. 1). Methodology recommended for VNN diagnosis by the Office Internationale des Epizooties (OIE 2003) was used for nucleic acid extraction and RT-PCR. Whole fish larvae (150 mg of tissue) were homogenized in a plastic tissue homogenizer (treated with $0.1 \%$ diethyl polycarbonate [DEPC] and autoclaved) with $0.5 \mathrm{ml}$ distilled water (DEPC treated), then centrifuged at $10000 \mathrm{~g}$ for $10 \mathrm{~min}$. The resultant supernatant was mixed with $40 \mu \mathrm{l}$ of proteinase K (1 mg $\mathrm{ml}^{-1}$ ) and $40 \mu \mathrm{l}$ of $1 \%$ sodium dodecyl sulfate (SDS), and incubated at room temperature for $30 \mathrm{~min}$. The suspension was centrifuged as above and the supernatant was used for total nucleic acid extraction (phenol-chloroform extraction procedures).

Two $\mu$ l of total RNA were subjected to reverse transcription using murine leukemia virus (M-MLV) reverse transcriptase. The cDNA was prepared using a RT-PCR kit (Bangalore Genei). Briefly, total nucleic acids were preheated at $90^{\circ} \mathrm{C}$ for $5 \mathrm{~min}$ and incubated at $42^{\circ} \mathrm{C}$ for $30 \mathrm{~min}$ in $20 \mu \mathrm{l} \mathrm{PCR}$ buffer $(10 \mathrm{mM}$ Tris/ $\mathrm{HCl}, \mathrm{pH} 8.3,50 \mathrm{mM} \mathrm{KCl}$ ) containing $2.5 \mathrm{U}$ murine leukaemia virus (M-MLV) reverse transcriptase (USB Corp.), $1.0 \mathrm{U}$ ribonuclease inhibitor, $0.5 \mu \mathrm{M}$ reverse primer, $1 \mathrm{mM}$ each of 4 deoxynucleotide triphosphates (dNTP), and $5 \mathrm{mM} \mathrm{MgCl}_{2}$. A reverse primer (5'-CGAGTC-AAC-ACG-GGT-GAA-GA-3') and a forward primer (5'-CGT-GTC-AGT-CAT-GTG-TCG-CT-3') were used for amplification of a target sequence (430 bases) of the RNA2 (Nishizawa et al. 1994). The amplified product was visualized using $2 \%$ agarose gel electrophoresis.

\section{RESULTS}

\section{Clinical observations}

The larvae were normal, and natural in pigmentation and behavior, feeding actively during the first week and part of the second week after hatching. Some of the larvae had abnormally darkened pigmentation at 9 to $10 \mathrm{dph}$, but were feeding normally. A majority of the larvae in the investigated batch (Fig. 1) housed next to the VNN-positive fry tanks became lethargic, with reduced feeding activity from $14 \mathrm{dph}$. This followed marked darkening of the body coloration and mortality by 16 to $20 \mathrm{dph}$. However, unlike the larvae from Tanks $\mathrm{A}$ and $\mathrm{B}$, where more than $70 \%$ of the larvae died due to VNN, mortality among the larvae in Tanks C, D and E was low (15 to $35 \%$ ). Mortality peaked at 18 to $20 \mathrm{dph}$ and gradually fell to less than 2 to $5 \%$ among surviving larvae by 24 to 25 dph.

\section{Histopathology}

Light and electron microscopy of whole larvae sampled on the day of hatching and at $2 \mathrm{dph}$ revealed no marked deviations from the normal histology of nerve tissues in either the brain or the eye. Mild necrotic vacuolation, as evidenced by the presence of fewer manifested cells, occurred in the retinal layers of larvae at 4 to $6 \mathrm{dph}$. At the same time, brain tissue showed histopathological manifestations typical of nerve necrosis. Necrotic nerve cells in the gray matter of the brain showing pyknotic and emarginated nuclei and vacuolated spinal neuronal layers were conspicuous in fish at 6 dph (Fig. 2a,b). Complete vacuolation of brain tissue occurred in moribund fish between 12 and $20 \mathrm{dph}$. Retinal vacuolation was clear in these samples (Fig. 2c). Kidney tubules and glomeruli were normal, while vacuolated necrosis was present in the liver of moribund and surviving larvae at 20 to 24 dph (Fig. 2d).

\section{Electron microscopy and immunostaining}

Localization in skin and musculature

An interesting virus localization pattern occurred in the skin and musculature of larvae at 4 to $6 \mathrm{dph}$ and 19 to $20 \mathrm{dph}$ (Fig. 3a-d). Moribund infected fry from 19 to $20 \mathrm{dph}$ had extensive localization of viral particles in the dermal musculature underlying the skin (Fig. 3b,d). Immuno-localization of viral particles was clearly indicated by immunopositive staining in the sub-cutis and epidermal layers in younger larvae at 

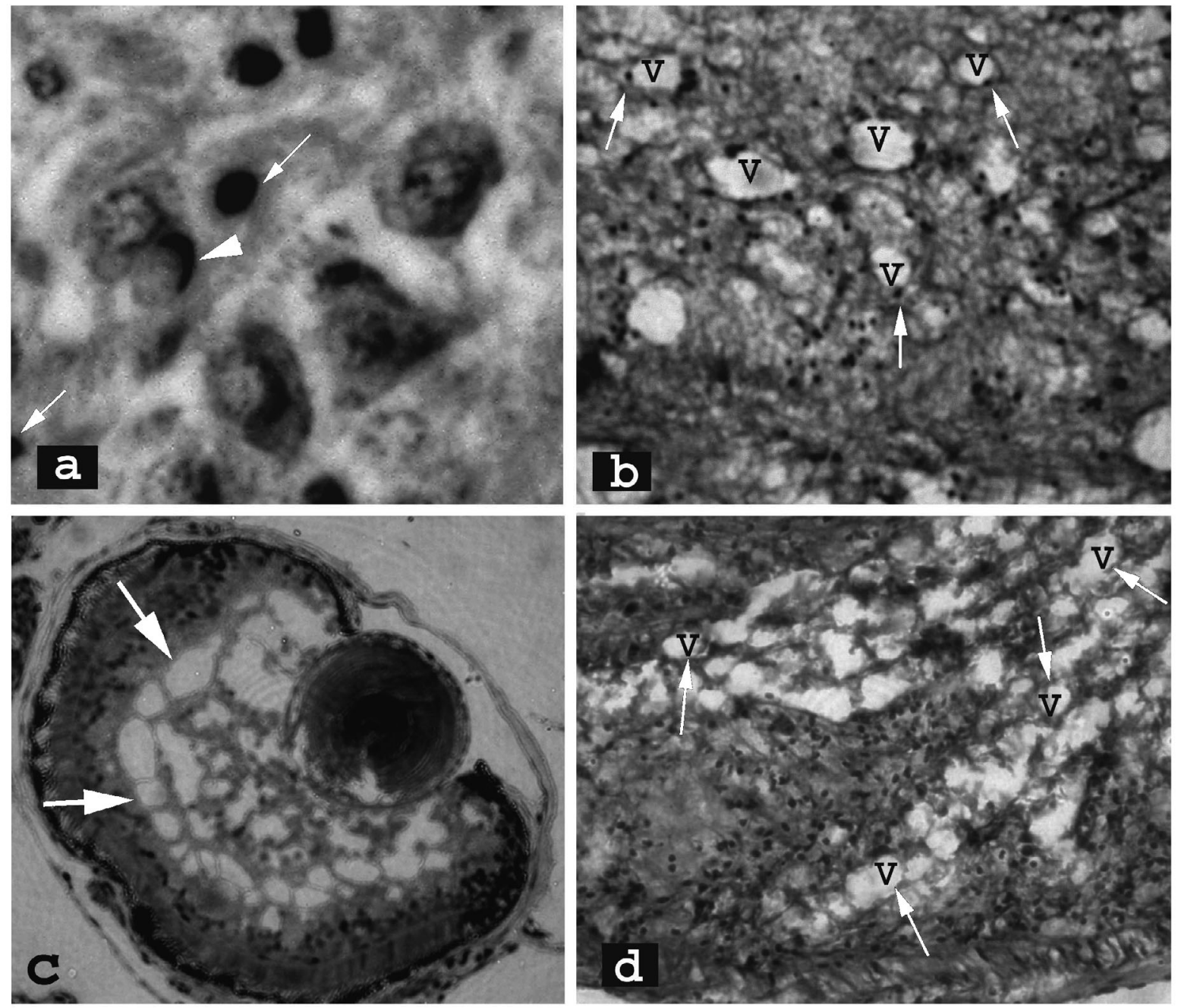

Fig. 2. Lates calcarifer. Histopathological manifestations (light microscopy, hematoxylin and eosin staining) in VNN affected larvae of Asian seabass at 0 to 40 days post-hatch (dph). (a) Nerve cells in the brain showing pyknotic (arrows) and emarginated nuclei (arrow head) in fish at $6 \mathrm{dph}$. (b) Highly vacuolated nerve cells (arrows) in the spinal cord in larvae at $6 \mathrm{dph}$. V= vacuole. (c) Vacuolated (arrows) retinal layers in moribund larvae at $20 \mathrm{dph}$. (d) Highly vacuolated hepatocytes (arrows) in moribund larvae at $20 \mathrm{dph} . \mathrm{V}=$ vacuole

6 dph (Fig. 3c). Electron microscopy also revealed icosahedral viral particles (30 $\mathrm{nm}$ diameter) in the intramuscular spaces under the skin (Fig. 3a).

\section{Brain and spinal cord}

As the infection continued, the spinal cord and brain neuronal tissue showed increasing necrotic manifestations. Different stages of progressive nerve cell necrosis of the brain and spinal cord neuronal layers occurred during the sub-clinical and clinical manifestation stages in larvae at 6 to $14 \mathrm{dph}$ (Fig. 4). We found normal and unaltered nerve cells of the brain (Fig. 4a) in the early stages, and formation of the multiple cyto- plasmic organelles with membrane-bound viral particles (Fig. 4b) just before the onset of clinical manifestations. Virus particles occurred in a characteristic necklace-like arrangement in the organelles (Fig. 4c). Loss of cell integrity and disarrayed cells with scattered nuclei (Fig. 4d), nuclear degeneration (Fig. 4e) and fibrotic necrosis of the nerve cells (Fig. 4f) completed the sequence of nerve cell necrosis. The viral particles were scattered in the necrotic nerve tissue. This stage (6 to $14 \mathrm{dph}$ ) corresponded to the clinical VNN-like manifestation stage.

As the mortality started, the larvae were tested (by RT-PCR) for the presence of piscine nodavirus. Moribund larvae from 16 to $20 \mathrm{dph}$ tested positive for the amplification of the RNA2 coat protein gene. 

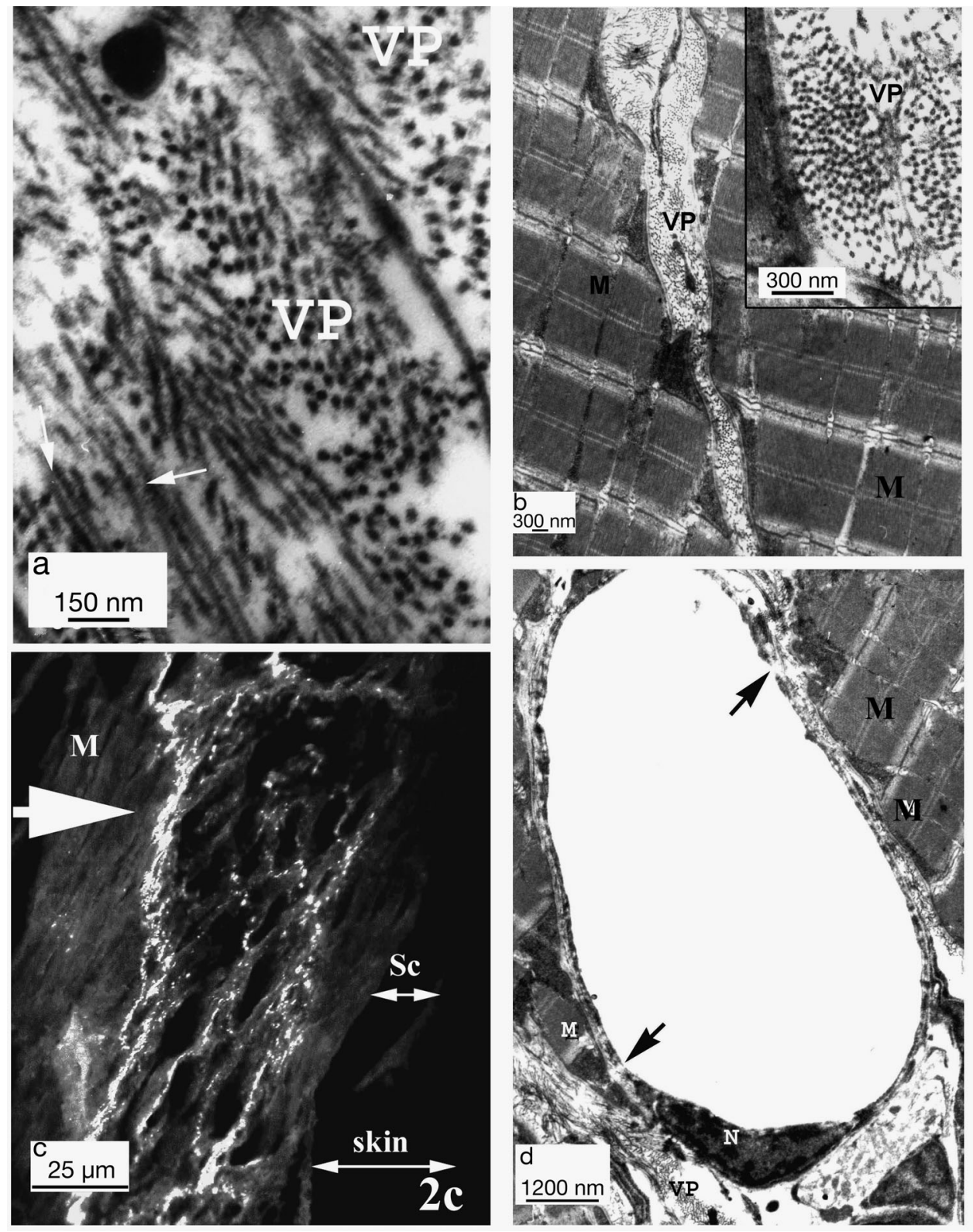

Fig. 3. Lates calcarifer. Nodavirus in dermal musculature of seabass larvae at 6 and 19 to 20 days post-hatch (dph). (a) Viral particles (VP) in the epidermal layers of larvae at $20 \mathrm{dph}$. Electron dense viral particles were 28 to $32 \mathrm{~nm}$ in diameter. Myofibrils of the dermal musculature (arrows). Electron micrograph. (b) Aggregation of viral particles (VP) in inter-myofibrillar (M) spaces of larvae sampled at $19 \mathrm{dph}$. Electron micrograph (c) Skin sections of the larvae (6 dph) stained with anti-NNV rabbit antibodies, labeled with FITC showing immunopositive intramuscular spaces. Immunofluorescence of the sub-cutis (thick arrow) indicates localization of the nerve necrosis virus in the epidermal layers. Scale pockets (short double-headed arrow) can be seen to the right of the fluorescent muscle layers. Immunofluorescence light micrograph (250x). (d) Nerve cell of a moribund larva (20 dph) within the dermal musculature $(\mathrm{M})$ with emarginated nucleus $(\mathrm{N})$ and emptied cytoplasm. The disintegrating cell membrane shows probable viral exit portals (arrows) and viral particles (VP) in the inter-myofibrillar spaces. Electron micrograph

\section{DISCUSSION}

Using nerve cell necrosis as an indicator, delayed responses have been reported in experimental VNN infection models. We also found that the onset of nerve necrosis in the brain and retinal layers took place only after the first week post hatch. Interestingly, the subcutis and the epidermal layers were filled with viral particles well before their occurrence in the tissues of the central nervous system (CNS). The proximity of viral particles to the external surface indicates probable entry routes into the early larval stages, and exit routes 
from the late larval stages. Nodaviruses are believed to spread along nerves (Nguyen et al. 1996), which may explain why we found cells of the CNS with viral particles only after $6 \mathrm{dph}$ and in the lateral musculature at 4 to $6 \mathrm{dph}$. Infectivity experiments show that uninfected larvae become infected with nodavirus when reared with the nodavirus-infected fish, or in medium containing infected tissue extract. An intra-peritoneal injec-
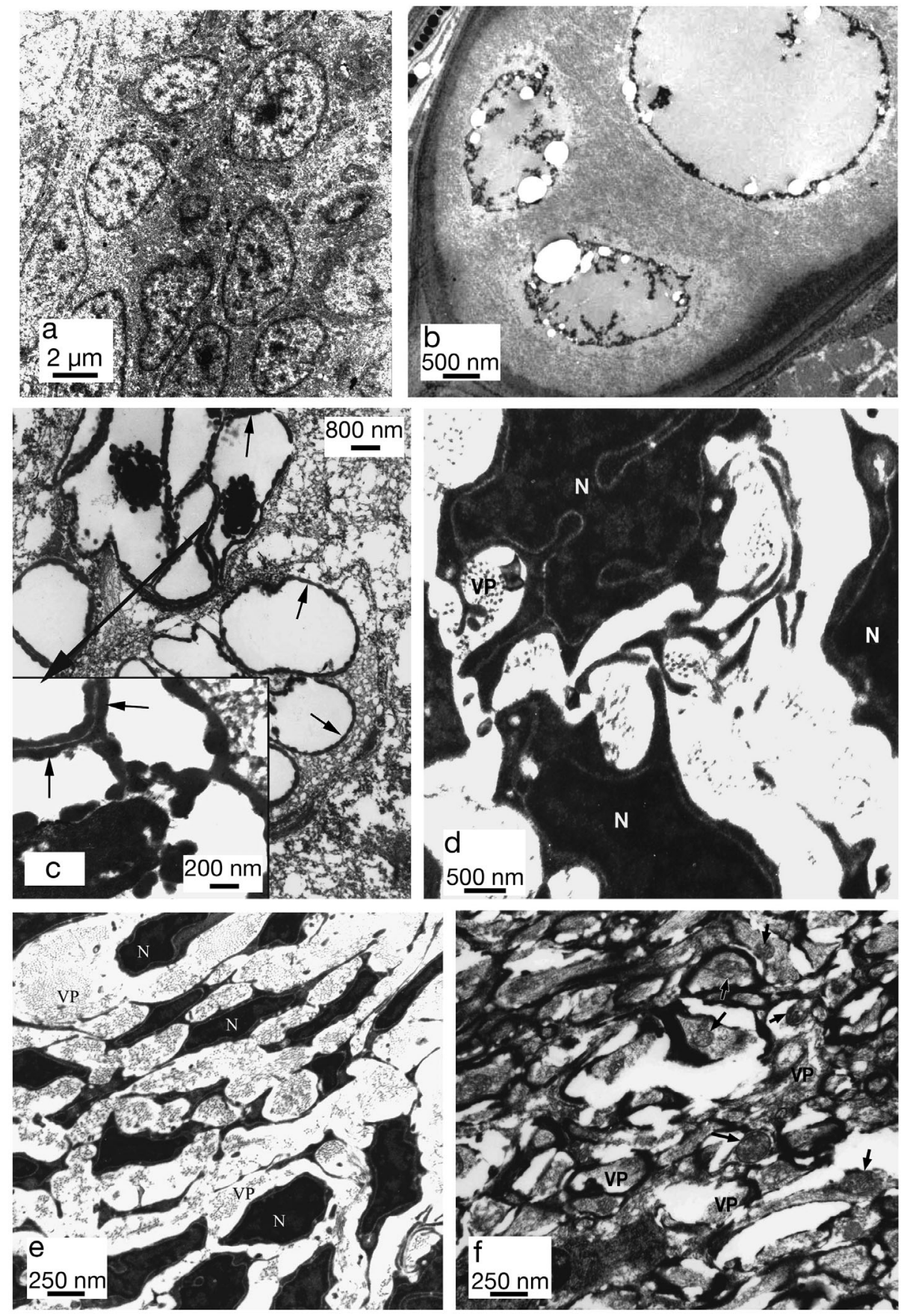

Fig. 4. Lates calcarifer. Stages of nerve cell necrosis in larvae of Asian seabass between 2 and 14 dph (d post-hatch). Electron micrographs. (a) Nerve cells of normal appearance in the brain of larvae at $4 \mathrm{dph}$. (b) Membrane bound viral particles typical of VNN in the nerve cell organelles of larvae at $6 \mathrm{dph}$. (c) Multiple aggregations of virus-containing cell organelles of larvae at $10 \mathrm{dph}$. Note the necklace-like arrangement of viral particles in the inset. (d) Loss of cell integrity and scattering of nuclei (N) with dispersed viral particles (VP) in the clinically affected larvae at $14 \mathrm{dph}$. (e) Nerve cell necrosis almost complete (larvae at 14 dph) with fibrotic degeneration of the nuclei (N). Viral particles (VP) scattered throughout. (f) Complete fibrotic necrosis of the nuclei, loss of tissue integrity and scattered mitochondria (small arrows) in neuronal tissues of larvae at $14 \mathrm{dph}$ 
tion challenge experiment with Atlantic halibut produced RT-PCR positivity for the presence of injected nodavirus in the neuronal tissue $13 \mathrm{~d}$ post challenge (Grove et al. 2003). The nodavirus was detected in the kidney earlier than in neuronal tissue (op. cit.), whereas we found that the kidney had normal histological features at a time when the liver showed necrotic vacuolation. In another study (Grotmol et al. 1999) using a water-borne challenge with infective tissue homogenate, mortality occurred after $3 \mathrm{wk}$.

Viral entry and detection are thought to be dependent on the mode of challenge. Hence, the localization of the nerve necrosis virus (NNV) that we found is a clear indication of infection from the water through the skin. Supporting evidence comes from a study of yellow grouper nerve necrosis virus (YGNNV) and its immunolocalization using monoclonal antibodies (Nguyen et al. 1996), which suggests that the virus probably enters the medial spinal cord through afferent nerves from the skin, and that the infection spreads anteriorly from there to the brain and retina, and posteriorly in the spinal cord. Our electron microscopy and immunostaining of sections of the skin and associated musculature clearly indicated the presence of NNV particles, supporting the view that NNV transmission probably occurs through the skin. However, the data are not sufficient to determine whether the VNNpositive older fish batch was solely responsible for viral transmission to the younger batch. Reductions in mortalities in subsequent batches of larvae, as observed in our study, are probably due to the reducing virulence of the virus (Totland et al. 1999, Castric et al. 2001). Horizontal transmission in the hatchery environment is the most likely source of VNN infections in Lates calcarifer (Munday et al. 1992). The virus localization pattern we found is of particular interest for the development of virus neutralization or vaccination strategies to enhance mucosal immunity during the early immune responsive developmental stages.

Once contracted, the virus reached the neuronal tissue of the CNS rapidly, and nerve necrosis set in. Clustering of organelles with membrane-bound viral particles, fusion of virus-rich organelles and emptying of the cytoplasm occurred as necrotic changes progressed. As the disease reached the clinical manifestation phase, the neuronal layers of the brain, spinal cord and the retina became progressively necrotic. The necklace-like arrangement of membrane-bound viral particles in the cytoplasm of the nerve cells that we observed is similar to those reported by Johansen et al. (2002). At morbidity, histopathological manifestations revealed disintegration of cell structure and complete fibroid degeneration of nerve cells, resulting in the clinical manifestations such as loss of reflexes, feeding instinct and swimming coordination.
Grotmol \& Totland (2000) suggested that VNN spreads to offspring from infected spawners. Piscine nodavirus occurs in the gonadal tissues of broodstock striped jack, kelp grouper, European seabass and Asian seabass (Arimoto et al. 1992, Nakai et al. 1994, Comps et al. 1996, Breuil et al. 2002). Though we detected the nodavirus in the ovarian samples in our earlier work, we were unable to conclude definitively that the oocyte per se contributed to nodavirus infection in Asian seabass larvae (Azad et al. 2006). Grotmol \& Totland (2000) showed that ozone-disinfected eggs from a VNN-positive halibut broodstock did not produce VNN, while the untreated eggs gave rise to VNN in the larvae, indicating that eggs were vectors of transmission. Contamination of the halibut hatching environment may also have promoted horizontal transmission of VNN to the hatchlings. Infectivity studies carried out by Brueil et al. (2001) in Dicentrarchus labrax using NNV-contaminated egg fertilization protocols and VNN induction in $4 \mathrm{~d}$ old larvae of the seabass showed that both routes (vertical transmission from eggs and horizontal transmission by contamination of the hatchling environment) produced VNN in the larvae. From all of these investigations it can be deduced that a combination of contaminated gonadal material (vertical transmission) and the epidermal entry of viral particles from the contaminated spawning environment (horizontal transmission) result in VNN infection at the particularly vulnerable larval stages.

Hence, it is important that all possible contamination routes and sources of the nodavirus be eliminated for VNN-free seed production. Strict procedures for carrier broodstock elimination, hatchery hygiene, stress reduction measures and separation or allocation of dedicated tools and facilities for rearing different batches of larvae have to be followed to reduce VNNassociated fish losses. Nodavirus localization in the skin and underlying musculature noticed in the present study indicate that virus neutralization strategies during early larval development could be employed as effective VNN prevention strategies.

Acknowlegements. The authors are thankful to the Director, Central Institute of Brackishwater Aquaculture, Chennai, India for the encouragement and suggestions. The authors also express their gratitude to the Christian Medical College \& Hospital for EM facilities (Mr. Jagannathan and Miss Rita, technical staff of the laboratory) and we especially thank the Professor in charge of EM laboratory. Cooperation and help extended by Mr. Subburaj and Mr. Thiagaraj, Fish Culture Division, CIBA is also gratefully acknowledged.

\section{LITERATURE CITED}

Arimoto M, Mori K, Nakai T, Muroga K, Furusawa I (1993) Pathogenicity of the causative agent of viral nervous necrosis disease in striped jack, Pseudocaranx dentex (Bloch \& Schneider). J Fish Dis 16:461-469 
Arimoto M, Mushiake K, Mizuta Y, Nakai T, Muroga K, Furusawa I (1992) Detection of striped jack nervous necrosis virus (SJNNV) by enzyme-linked-immuno-sorbent-assay (ELISA). Fish Pathol 27:191-195

Azad IS, Shekhar MS, Thirunavukkarasu AR, Poornima M and 5 others (2005) Nodavirus infection causes mortalities in hatchery produced larvae of Lates calcarifer: first report from India. Dis Aquat Org 63:113-118

Azad IS, Jithendran KP, Shekhar MS, Thirunavukkarasu AR, de la Pena LD (2006) Immunolocalisation of nerve necrosis virus indicates vertical transmission in hatchery produced Asian seabass (Lates calcarifer Bloch) - a case study. Aquaculture 255:39-47

Breuil G, Mouchel O, Fauvel C, Pepin JF (2001) Seabass Dicentrarchus labrax nervous necrosis virus isolates with distinct pathogenicity to seabass larvae. Dis Aquat Org 45: 25-31

Breuil G, Pepin JFP, Boscher S, Thiéry R (2002) Experimental vertical transmission of nodavirus from broodfish to eggs and larvae of the seabass, Dicentrarchus labrax (L.). J Fish Dis 25:697-702

Castric J, Thiéry R, Jeffroy J, de Kinkelin P, Raymond JC (2001) Sea bream Sparus aurata, an asymptomatic contagious fish host for nodavirus. Dis Aquat Org 47:33-38

Chi SC, Shieh JR, Lin SJ (2003) Genetic and antigenic analysis of betanodaviruses isolated from aquatic organisms in Taiwan. Dis Aquat Org 55:221-228

Comps M, Trindadem M, Delsert C (1996) Investigations of fish encephalitis virus (FEV) expression in marine fishes using DIG-labelled probes. Aquaculture 143:113-121

Glazebrook JS, Heasman MP, de Beer SW (1990) Picorna-like viral particles associated with mass mortalities in larval barramundi, Lates calcarifer Bloch. J Fish Dis 13:245-249

Grotmol S, Totland GK (2000) Surface disinfection of Atlantic halibut Hippoglossus hippoglossus eggs with ozonated seawater inactivates nodavirus and increases survival of the larvae. Dis Aquat Org 39:89-86

Grotmol S, Bergh Ø, Totland GK (1999) Transmission of viral encephalopathy and retinopathy (VER) to yolk-sac larvae of the Atlantic halibut Hippoglossus hippoglossus: occurrence of nodavirus in various organs and a possible route of infection. Dis Aquat Org 36:95-106

Grove S, Johansen R, Dannevig BH, Reitan LJ, Ranheim T (2003) Experimental infection of Atlantic halibut Hippoglossus hippoglossus with nodavirus: tissue distribution and immune response. Dis Aquat Org 53:211-221

Hegde A, The HC, Lam TJ, Sin YM (2003) Nodavirus infection in freshwater ornamental fish, guppy, Poicelia reticulata-comparative characterization and pathogenicity studies. Arch Virol 148:576-586

Johansen R, Ranheim T, Hansen MK, Taksdal T, Totland GK (2002) Pathological changes in the juvenile Atlantic halibut Hippoglossus hippoglossus persistently infected with nodavirus. Dis Aquat Org 50:161-169

Johansen R, Grove S, Svendsen AK, Modahl I, Dannevig B (2004) A sequential study of pathological findings in Atlantic halibut, Hippoglossus hippoglossus (L.), throughout one year after an acute outbreak of viral encephalopathy and retinopathy. J Fish Dis 27:327-341

Le Breton A, Grisez L, Sweetman J, Ollevier F (1997) Viral nervous necrosis (VNN) associated with mass mortalities

Editorial responsibility: Jo-Ann Leong,

Kaneohe, Hawaii, USA in cage-reared seabass, Dicentrarchus labrax (L.). J Fish Dis 20:145-151

Mori K, Nakai T, Muroga K, Arimoto M, Mushiake K, Furusawa I (1992) Properties of a new virus belonging to Nodaviridae found in larval striped jack (Pseudocaranx dentex) with nervous necrosis. Virology 187:368-371

Munday BL, Nakai T (1997) Special topic review: nodaviruses as pathogens in larval and juvenile marine finfish. World $\mathrm{J}$ Microbiol Biotech 13:375-381

Munday BL, Langdon JS, Hyatt A, Humphrey JD (1992) Mass mortality associated with a viral-induced vacuolating encephalopathy and retinopathy of larval and juvenile barramundi, Lates calcarifer Bloch. Aquaculture 103: 197-211

Munday BL, Kwang J, Moody N (2002). Betanodavirus infections of teleost fish: a review. J Fish Dis 25:127-142

Nakai T, Nguyen HD, Nishizawa T, Muroga K, Arimoto M, Ootsuki K (1994) Occurrence of viral nervous necrosis in kelp grouper and tiger puffer. Fish Pathol 29:211-212

Nishizawa T, Mori K, Nakai T, Furusawa I, Muroga K (1994) Polymerase chain reaction (PCR) amplification of RNA of striped jack nervous necrosis virus (SJNNV). Dis Aquat Org 18:103-107

Nguyen HD, Nakai T, Muroga K (1996) Progression of striped jack nervous necrosis virus (SJNNV) infection in naturally and experimentally infected striped jack Pseudocaranx dentex larvae. Dis Aquat Org 24:99-105

OIE (Office Internationale des Epizooties) (2003) Viral encephalopathy and retinopathy or viral nerve necrosis. In: OIE diagnostic manual for aquatic animal diseases. Office Internationale des Epizooties, Paris

Péducasse S, Castric J, Thiéry R, Jeffroy J, Le Ven A, Baudin Laurencin FB (1999) Comparative study of viral encephalopathy and retinopathy in juvenile sea bass Dicentrarchus labrax infected in different ways. Dis Aquat Org 36:11-20

Roberts RJ (1978) Fish Pathology. Bailliere Tindall, London

Skliris GP, Richards RH (1999) Nodavirus isolated from infected tilapia (Oreochromis mossambicus). J Fish Dis 22: 315-318

Skliris GP, Krondiris JV, Sinderis DC, Shinn AP, Starkey WG, Richards RH (2001) Phylogeny and antigenic characterization of new fish nodavirus isolates from Europe and Asia. Virus Res 75:59-67

Tanaka S, Aoki H, Nakai T (1998) Pathogenicity of the nodavirus detected from diseased seven band grouper Epinephelus septemfasciatus. Fish Pathol 33:31-36

Tanaka S, Kuriyama I, Nakai T, Miyazaki T (2003) Susceptibility of cultured juveniles of several marine fish to the seven band grouper nerve necrosis virus. J Fish Dis 26: $109-115$

Totland GK, Grotmol S, Morita Y, Nishioka T, Nakai T (1999) Pathogenicity of nodavirus strains from striped jack, Pseudocaranx dentex and Atlantic halibut Hippoglossus hippoglossus, studied by waterborne challenge of yolksac larvae of both teleost species. Dis Aquat Org 38: $169-175$

Zafran, Harada T, Koesharyani I, Yuasa K, Hatai K (1998) Indonesian hatchery reared seabass larvae (Lates calcarifer) associated with viral nervous necrosis (VNN). Indonesian Fish Res J 4:19-22

Submitted: May 7, 2005; Accepted: August 10, 2006

Proofs received from author(s): November 25, 2006 